
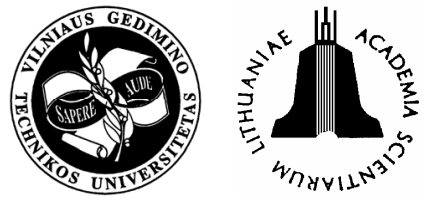

\title{
CRACKING AND STRENGTH OF REINFORCED CONCRETE STRUCTURES IN FLEXURE STRENGTHENED WITH CARBON FIBRE LAMINATES
}

\author{
Juozas Valivonis, Tomas Skuturna \\ Dept of Reinforced Concrete and Masonry Structures, Vilnius Gediminas Technical University, \\ Sauletekio al. 11, LT-10223 Vilnius, Lithuania. E-mail: gelz@st.vgtu.lt \\ Received 18 June 2007; accepted 17 Oct 2007
}

\begin{abstract}
The article presents the analysis of the cracking moment and the strength of beams reinforced with external carbon fibre. Experimental research of beams strengthened in this way has been carried out. Three different methods of anchoring external reinforcement were applied to strengthen the beams. The influence of anchorage on the cracking moment and the strength of the beams has been defined. Design methods for defining the cracking moment and the strength have been presented. The design procedure for defining the cracking moment evaluates the curvilinear stress diagrams of concrete under tension and compression. The design procedure for defining the strength of the structures evaluates the stiffness of the contact between the carbon fibre and the concrete. The design results are provided. Comparative analysis of the experimental and the theoretical results has been performed.
\end{abstract}

Keywords: external carbon fibre reinforcement, strengthening, cracking moment, strength.

\section{Introduction}

Bonding of external carbon fibre reinforcement to the reinforced concrete members is widely accepted and is considered to be an effective and convenient method of reinforcement among many methods of strengthening different constructions. Such a way of strengthening has many advantages in comparison with the traditional methods, mainly due to excellent mechanical properties of the fibre: high strength at tension, resistance to aggressive environment, light weight.

Laboratory experiments, theoretical calculations and numerical simulation show that strengthening the reinforcement with external carbon fibre in the tension zone of the reinforced concrete beam considerably increases the strength at bending, reduces deflections as well as cracks width. Strengthening the reinforced concrete constructions with external reinforcement changes their behaviour under load and failure pattern. Most often the strengthened members fail in a brittle way, mainly due to the loss of connection between the composite material and the concrete [1-6]. Only integrated work of the carbon fibre and the strengthened member may ensure an effective use of the fibre. Bond between external reinforcement and concrete is influenced by several variables, such as measurements of concrete members and fibre, properties of concrete and adhesive, methods of anchoring carbon fibre [7-11]. Research conducted by many authors shows that depending on the way of fastening external carbon fibre reinforcement and its quantity, the behaviour, strength and the failure pattern of the strengthened member change. The way of anchoring carbon fibre as well as its quantity largely determines crack formation in strengthened constructions.
Research results received by many authors show that the cracking moment in reinforced concrete beams with carbon fibre reinforcement may increase from $12 \%$ to $230 \%$. In strengthened flexural members cracks are found in bigger numbers and closer to each other; however, they are narrower than in beams without external reinforcement [12-18].

\section{Experimental research}

12 reinforced concrete beams from heavy-weight concrete were made for experimental research. Material used for making concrete: Portland cement, quartz sand and crushed gravel. Properties of the materials are provided in Tables 1-4.

Reinforced concrete beams were reinforced with $\emptyset 6$ reinforcing bars. Transverse reinforcement $\varnothing 8$ bars spaced at $100 \mathrm{~mm}$ from each other.

The width of the carbon fibre strip - $100 \mathrm{~mm}$.

Prior to pasting, all beams were cleaned with steel brushes and fat was removed from them. Carbon fibre was glued by using epoxy glue.

Table 1. Concrete material properties

\begin{tabular}{lcc}
\hline Compressive strength $f_{c}, \mathrm{~N} / \mathrm{mm}^{2}$ & 32,87 & 38,27 \\
Tensile strength $f_{c t}, \mathrm{~N} / \mathrm{mm}^{2}$ & 2,53 & 3,03 \\
Elasticity modulus $E_{c m}, \mathrm{GPa}$ & 31,45 & 34,10 \\
\hline
\end{tabular}

Table 2. Steel bar reinforcement properties

\begin{tabular}{ll} 
Yield stress $f_{y}, \mathrm{~N} / \mathrm{mm}^{2}$ & 358 \\
Maximum stress $f_{u}, \mathrm{~N} / \mathrm{mm}^{2}$ & 460 \\
Elasticity modulus $E_{s}, \mathrm{GPa}$ & 205 \\
\hline
\end{tabular}


Table 3. Carbon fibre reinforcement properties

\begin{tabular}{lc} 
Tensile strength $f_{e}, \mathrm{~N} / \mathrm{mm}^{2}$ & 3800 \\
Elasticity modulus $E_{e}, \mathrm{GPa}$ & 231 \\
\hline
\end{tabular}

Table 4. Epoxy glue properties

\begin{tabular}{lc}
\hline Compressive strength $f_{g c}, \mathrm{~N} / \mathrm{mm}^{2}$ & 90 \\
Tensile strength $f_{g t}, \mathrm{~N} / \mathrm{mm}^{2}$ & 32 \\
Elasticity modulus $E_{g}, \mathrm{GPa}$ & 5100 \\
\hline
\end{tabular}

External reinforcement at supports was anchored in different ways. The external reinforcement of two beams (SA6-1, SA6-2) was glued by overlapping it with the supports. Two beams (SB6-1, SB6-2) were strengthened with carbon fibre only at the span. Carbon fibre reinforcement in SC6 series beams was anchored with cotters, the external reinforcement overlapping up to the supports. External reinforcement in two more beams (SD6 series) was anchored at the supports by fixing carbon fibre hoops. The control beam SK6-1 had no carbon fibre reinforcement (Figs 1-6). Fig 7 shows the loading arrangement for experimental test.
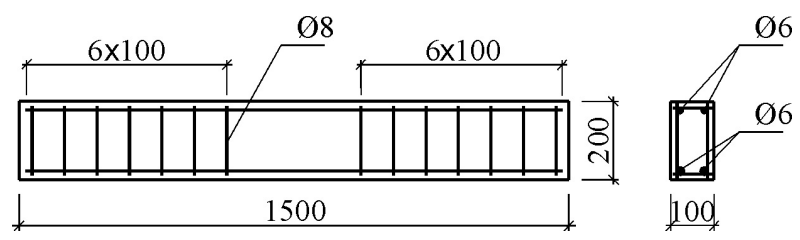

Fig 1. Reinforcement layout of beams

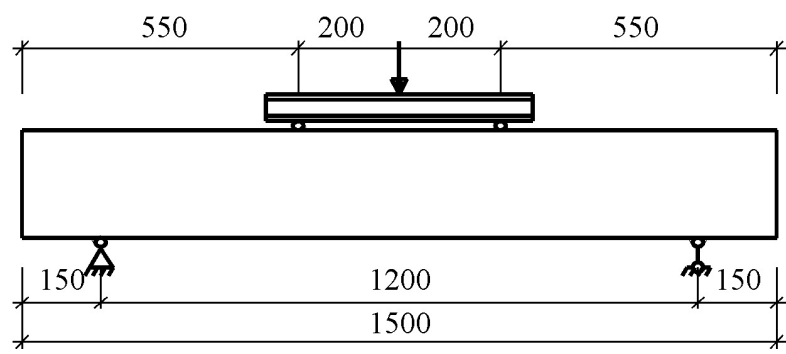

Fig 2. The control beam SK6-1 configuration

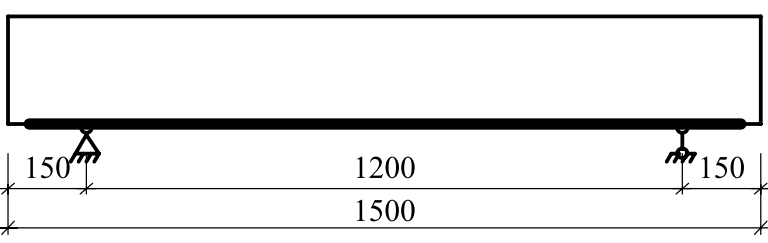

Fig 3. The external reinforcement of SA6 series beams

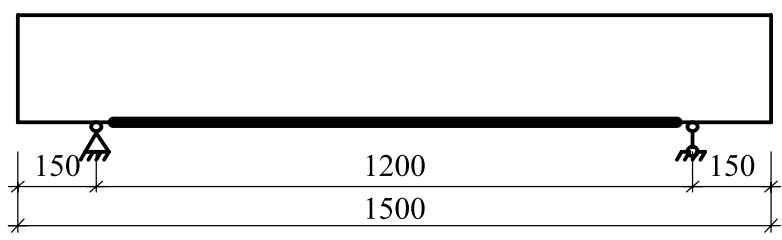

Fig 4. The external reinforcement of SB6 series beams

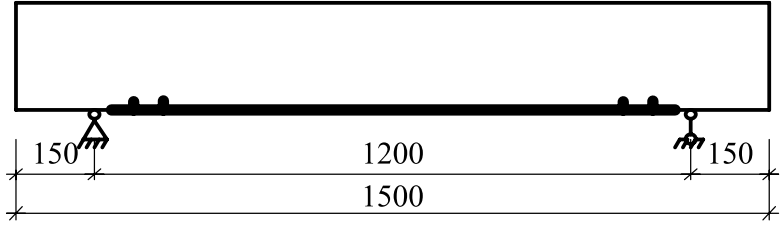

Fig 5. The external reinforcement of SC6 series beams

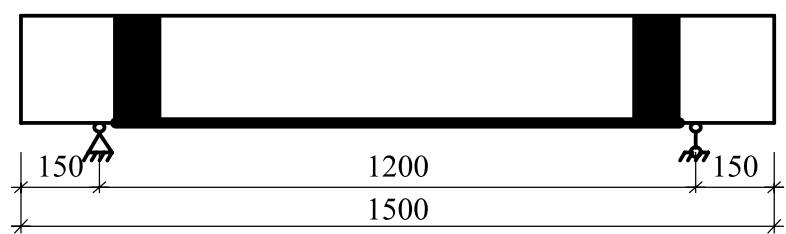

Fig 6. The external reinforcement of SD6 series beams

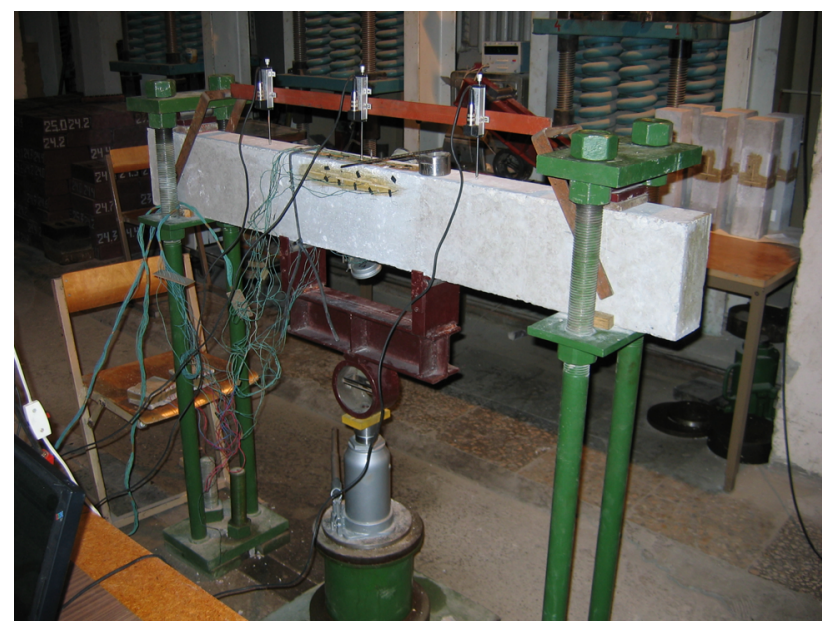

Fig 7. Bending test set up

The conducted research shows that in reinforced concrete beams strengthened with carbon fibre not only does the load-bearing capacity increase and deflections decrease, its resistance to cracking increases.

Carbon fibre is pasted to reinforced concrete beams with epoxy glue. Our research shows that the modulus of elasticity and elasticity in shear of the epoxy glue are much smaller than the modulus of elasticity and elasticity in shear of concrete. Therefore, if the carbon fibre at the tension zone of the beams is pasted without any additional anchorage, shear strains may appear. Due to these strains, carbon fibre may move in respect to the concrete. However, our research shows that at the initial stage of the work of the beams (prior to cracking) these shear strains are insignificant. One may state that at this stage carbon fibre and concrete work together. Besides, the biggest tension plane in the beam layer is covered with carbon fibre at its whole width. The modulus of elasticity of carbon fibre at tension is by about 7 times bigger than the modulus of elasticity of concrete. Therefore external fibre reinforcement of the flexural reinforced concrete member restricts the strains in concrete tension. Since prior to cracking concrete and carbon fibre work together, also the critical tension strains of the fibre are much bigger than those of the concrete. As a result, the critical 
tension strains of the concrete increases [19]. This determines the appearance of a decreasing $\delta$ - $\varepsilon$ diagram strain in concrete at tension. This means that the cracking moment in a strengthened reinforced concrete member with a restricted tension zone significantly increases. It has also been found that carbon fibre reinforcement in the tension zone influences expansion of cracks, restricts the cracks development, therefore the width and height of the cracks do not increase.

When stresses are big, a horizontal crack appears in the cracking zone. These cracks develop at around $5 \mathrm{~mm}$ distance from the surface of the tension zone of the flexural member. If the load keeps increasing, horizontal cracks join and break the contact between the concrete and carbon fibre. The method of fixing the external reinforcement influences the position and the development of the cracks.

Different methods of anchoring carbon fibre have no significant influence in the first working stage (before cracking) of the strengthened beams. The efficiency of external reinforcement anchorage is evident in other stages of action when the limit of yield stress of bar reinforcement is reached, the strength stresses are exceeded.

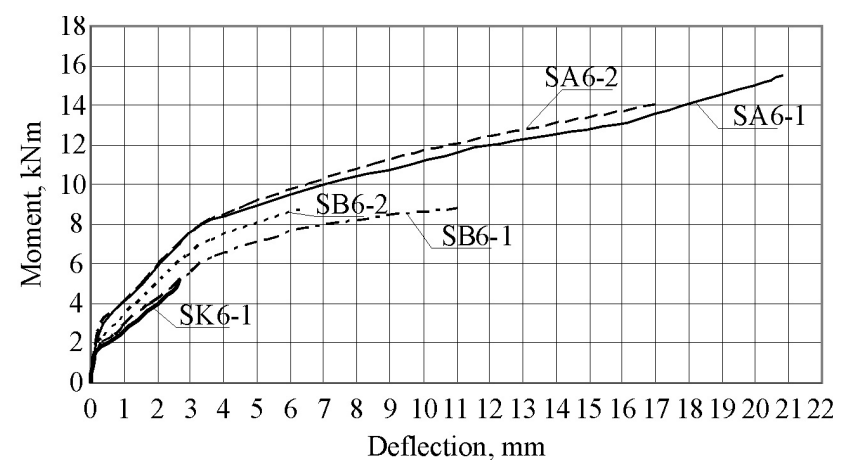

Fig 8. Experimental results of SA6 and SB6 series beams

The cracking moment in the beams with external carbon reinforcement differs by $10 \%$. Cracks in beams with this reinforcement and additional anchors appear no later than in beams where these anchors are absent.

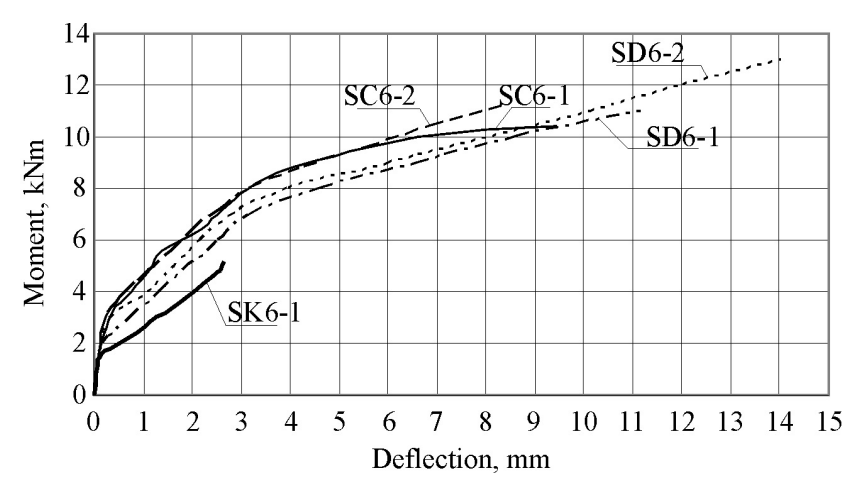

Fig 9. Experimental results of SC6 and SD6 series beams
Comparison of the cracks development manner in strengthened beams and beams without external carbon fibre reinforcement shows that there are fewer cracks in non-strengthened beams; however, they are much wider. More cracks are in beams with carbon fibre reinforcement; however, they are narrower and closer to each other. The cracking moment in beams with carbon fibre reinforcement significantly increases in comparison with such a moment in non-strengthened beams. Research shows that the cracking moment mostly increases in beams whose external carbon fibre reinforcement overlaps the supports. The difference is $100-106 \%$. In case when carbon fibre is not anchored with additional anchors or anchored with cotters, the cracking moment increases by $\sim 87 \%$. If we compare the cracking moment of the nonstrengthened beams and beams with external reinforcement when the carbon fibre is anchored with hoops, the difference is $100 \%$.

Our results show that the most effective way of anchoring external reinforcement to increase the cracking moment is overlapping carbon fibre with the supports (Figs 8, 9). The crack patterns at collapse for the tested beams are in Figs 10-12.

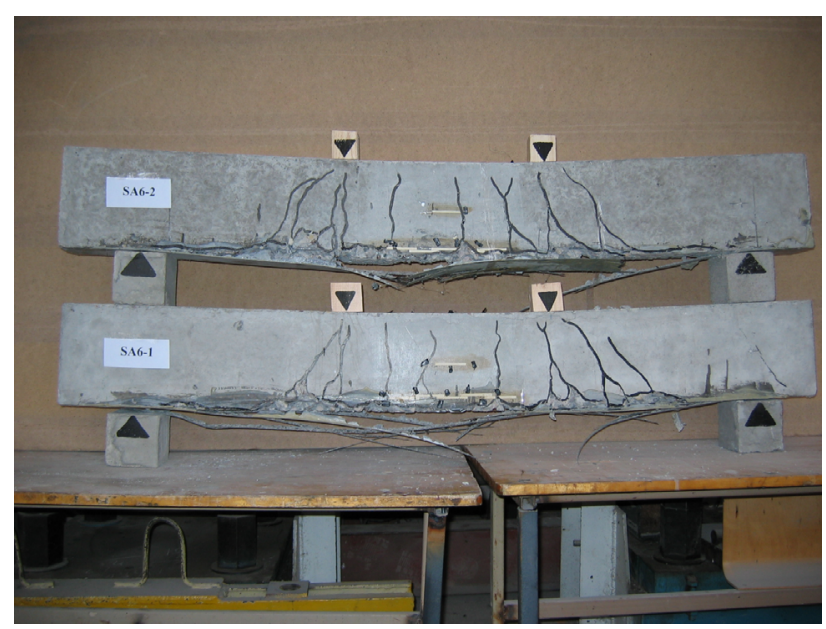

Fig 10. Crack pattern of SA6 series beams

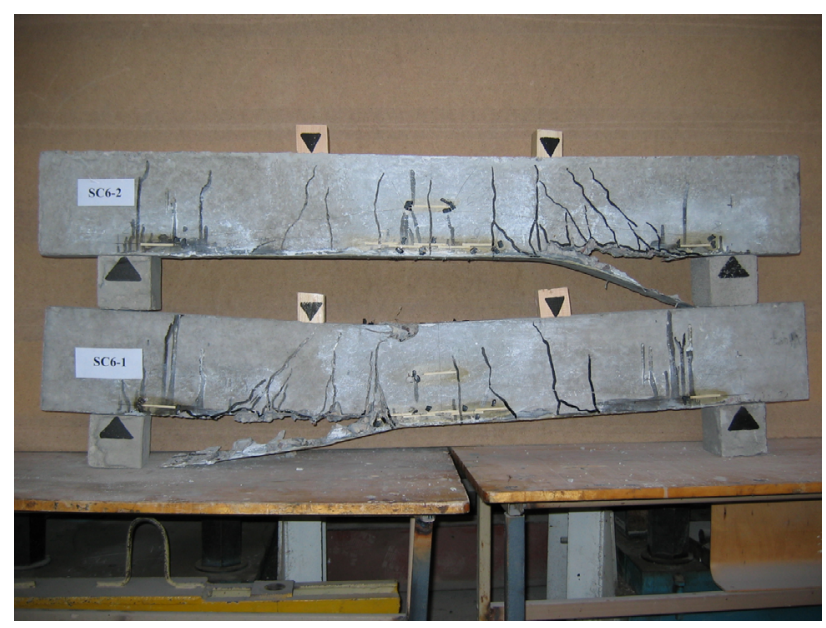

Fig 11. Crack pattern of SC6 series beams 


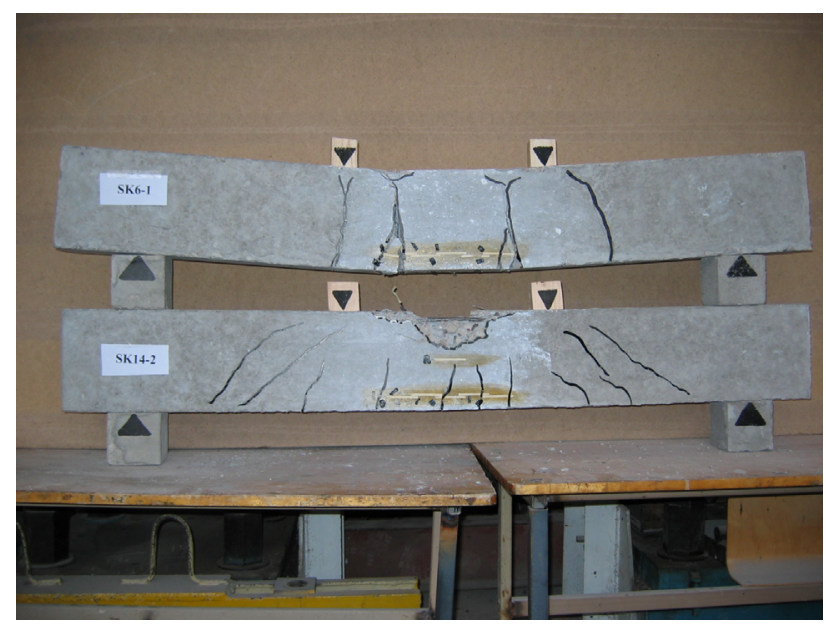

Fig 12. Crack pattern of control SK6 beams

The experiments show that, when cracking develops, the slip between carbon fibre and concrete appears in further stages of the action of strengthened structures. Displacement of external reinforcement in respect to concrete has big influence on the beams strength.

The research shows that, when concrete beams are reinforced with carbon fibre, their strength increases by $42-190 \%$. The strength is considerably influenced by the method of reinforcement anchorage. When carbon fibre in anchored by overlapping it over the support, the strength increases by 150-190\%. The strength increases by $48 \%$, when carbon fibre is not anchored with additional anchors. If we compare the strengths of the strengthened SC series beams (external reinforcement is anchored with cotters) and the control beam, the difference will reach $81 \%$. The strength of SD beams whose external reinforcement is anchored with carbon fibre hoops increases by $107 \%$.

It has been revealed by research that the highest effect of strengthening is achieved when external reinforcement overlaps supports. The strength of SA series beams is higher by $82 \%$ than that of the beams of SB series where carbon fibre is not anchored with additional anchors. The strength of the beams with cotters at the anchorage zone increases by $22 \%$ in comparison with SB series samples. When carbon fibre hoops are used in external anchorage, the beams strength is higher by $40 \%$ than that of the beams where external reinforcement is not anchored additionally.

\section{Design methods}

The design method for defining the cracking moment in flexural reinforced concrete members strengthened with external carbon fibre are analysed in this paper.

The design method is based on the following assumptions:

- strains in the cross-section of a reinforced concrete member vary proportionally;

- curvilinear diagrams are used to describe compressed concrete and concrete in tension;

- the external reinforcement works elastically. The design scheme is provided in Fig 13.

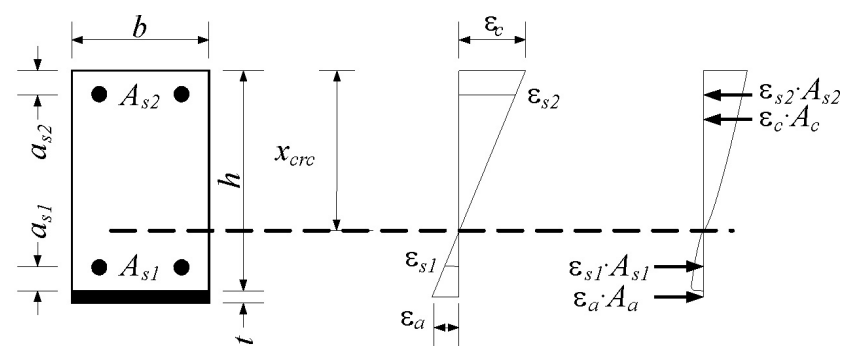

Fig 13. The design scheme defining the cracking moment

$$
\begin{aligned}
& M_{c r c}=\frac{c \cdot f_{c t}}{h-x_{c r c}}\left[\begin{array}{l}
\frac{f_{c}}{E_{c m}}\left(2 I_{c}-\frac{c \cdot f_{c t}}{E_{c m} \cdot \varepsilon_{c r}\left(h-x_{c r c}\right)} \cdot J_{c}\right) \\
+I_{c t}-\frac{0,25 c}{h-x_{c r c}} \cdot J_{c t}+\alpha_{s 2} \cdot I_{s 2} \\
+\alpha_{s 1} \cdot I_{s 1}+\alpha_{e} \cdot I_{e}
\end{array}\right], \\
& \frac{f_{c}}{E_{c m} \cdot \varepsilon_{c r}}\left[2 S_{c}-\frac{c \cdot f_{c t}}{E_{c m} \cdot \varepsilon_{c r} \cdot\left(h-x_{c r c}\right)} I_{c}\right]+\alpha_{s 2} \cdot S_{s 2}= \\
& S_{c t}-\frac{0.25 c}{h-x_{c r c}} I_{c t}+\alpha_{s 1} \cdot S_{s 1}+\alpha_{e} \cdot S_{e} \text {, }
\end{aligned}
$$

$M_{c r c}$ - cracking moment; $c$ - the ratio of critical and elastic deformations in concrete at tension; $x_{c r c}-$ depth of compressive zone; $f_{c}$ - compressive strength of concrete; $f_{c t}$ - tensile strength of concrete, $E_{c m}$ - concrete elasticity modulus, $I_{c}, I_{c t}, I_{s 1}, I_{s 2}, I_{e}$ - moments of inertia of compressed concrete, concrete in tension, reinforcement in tension, compression and external reinforcement in respect to the neutral axis; $\varepsilon_{c r}$ - compressive strain of concrete when $\sigma_{c}=f_{c} ; \alpha_{s 1} \alpha_{s 2} \alpha_{e}$ - ratio of the elasticity modulus of reinforcement in tension, compression and external reinforcement to the concrete elasticity modulus; $S_{c}, S_{c t}, S_{s 1}, S_{s 2}, S_{e}$ - statical moments of inertia around the neutral axis in compressed concrete, concrete at tension, reinforcement at tension, compression and external reinforcement. $J_{c}, J_{c t}-$ geometric characteristic of compressed concrete and concrete at tension.

$$
\begin{gathered}
J_{c}=\frac{b x_{c r c}^{4}}{4}, \\
J_{c t}=\frac{b\left(h-x_{c r c}\right)^{4}}{4} .
\end{gathered}
$$

The strength of the structures reinforced with external carbon fibre can be estimated by applying the theory of built-up bar [20]. The experimental research shows that during the estimation it is necessary to evaluate the stiffness of the carbon fibre and concrete connection. The design procedure is based on the following assumptions: stresses of concrete under compression are stable and equals $\sigma_{c}=f_{c}$; stresses of tensile steel reinforcement $\sigma_{s}=f_{y}$; stresses of carbon fibre $\sigma_{e}=f_{e}$; the contact of carbon fibre and concrete is not rigid. The design scheme for calculations is in Fig 14. 


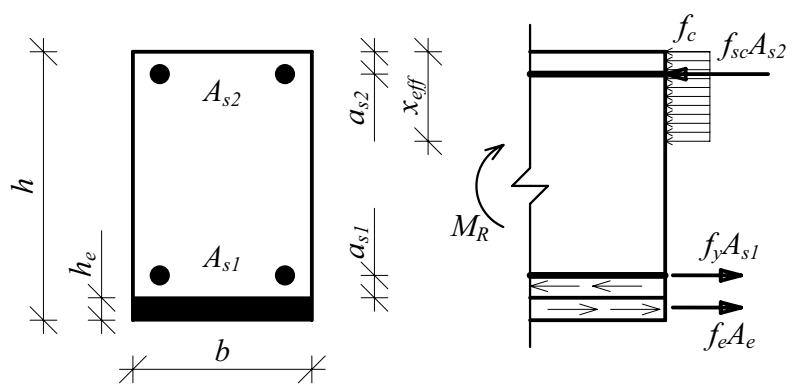

Fig 14. The design scheme for strength calculation

The strength of the reinforced concrete structure under bending strengthened with external carbon fibre reinforcement with the assessment of the stiffness of the existing contact is received by formula 5 :

$$
M_{R}=k(x) \cdot M_{R 0} \text {. }
$$

To calculate the strength $M_{R 0}$ of the reinforced concrete structure under assumption that the contact between carbon fibre and concrete is absolutely stiff, formula 6 is applied:

$$
\begin{aligned}
& M_{R 0}=f_{e} \cdot A_{e}\left(h-0,5 x_{e f f}-0,5 h_{e}\right)+ \\
& f_{y} \cdot A_{s 1}\left(h-0,5 x_{e f f}-a_{s 1}\right) .
\end{aligned}
$$

The coefficient which assesses the stiffness of the contact between carbon fibre reinforcement and concrete is calculated by equation:

$$
k(x)=\left(1-\frac{\operatorname{ch}(\lambda \cdot(0,5 l-a))}{\lambda \cdot x \cdot \operatorname{ch}(0,5 \lambda \cdot l)} \cdot \operatorname{sh}(\lambda \cdot x),\right.
$$

where: $l$ - the beam length; $a$ - the distance from the support to the first concentrated force; $x$ - the distance from the support to the dangerous section where the structure strength is being checked.

The value $\lambda$ assessing the stiffness of the contact is calculated by the formulas:

$$
\begin{gathered}
\lambda=\sqrt{\alpha \cdot \gamma}, \\
\alpha=\frac{b \cdot G_{\text {weff }}}{z}, \\
\gamma=\frac{1}{E_{c m} \cdot A_{e f f}}+\frac{1}{E_{e} \cdot A_{e}}+\frac{z^{2}}{E_{c m} \cdot I_{e f f}},
\end{gathered}
$$

where $E_{c m}, E_{e}$ - moduli of elasticity of concrete and carbon fibre; $A_{\text {eff }}$ and $I_{\text {eff }}$ - the area of reciprocal reinforced concrete cross-section and the moment of inertia, $z$ - the distance from the weight centre of the structure and the centre of carbon fibre.

The characteristics $G_{w e f f}$ of the stiffness of the contact in respect to the shear was identified by experimental research and can be calculated applying the formula:

$$
G_{\text {weff }}=0,001 \cdot K \cdot E_{c m},
$$

where $K$ - the coefficient evaluating the method of anchoring external reinforcement (Table 5).
Table 5. The coefficient K

\begin{tabular}{c|l}
\hline $\mathrm{K}$ & \multicolumn{1}{|c}{ The method of anchoring external reinforcement } \\
\hline 1 & CFRP is not anchored \\
\hline 1,5 & CFRP anchored with cotters \\
\hline 2 & CFRP anchored with carbon fibre hoops \\
\hline 37 & CFRP overlaps the supports \\
\hline
\end{tabular}

The height of the compression zone of reinforced concrete beam is calculated by the formula:

$$
x_{e f f}=\frac{f_{e} \cdot A_{e}+f_{y} \cdot A_{s 1}-f_{s c} \cdot A_{s 2}}{f_{c} \cdot b},
$$

where $f_{c}, f_{e}, f_{y}, f_{s c}$ - strengths of concrete under compression, carbon fibre, tensile and compressed steel reinforcement; $b$ - the cross-section area.

\section{Comparison of experimental and theoretical re- search results}

Calculations of experimental beams were performed with the help of the provided design methods. The results are in Tables 6-9. They show that it is possible to define rather exact cracking moment by a theoretical method. The calculated and the experimental cracking moments differ by $0,8-23,6 \%$ (Table 6). Analysis of methods shows that the calculation exactness mainly depends on the concrete properties. Calculations of cracking moments in beams whose ultimate concrete strength and elasticity modulus are bigger with the help of provided design methods are more exact $(0,8-8 \%)$ than in beams where concrete is weaker $(0,9-23,6 \%)$.

Calculations by experimental results of other authors [21-23] were made too. The difference is $19,8-27,9 \%$ (Table 7).

The calculated and the experimental strengths of strengthened beams are rather coincidental. The difference of results is $6,2-28,4 \%$ (Table 8 ). It shows that this design method can be applied for calculating structures in flexure strengthened with external reinforcement. Application of this method gave a good agreement with experimental strengths in [24-29] (Table 9).

Table 6. Comparison of experimental and calculated cracking moments

\begin{tabular}{c|c|c|c}
\hline Beam & $\begin{array}{c}\text { Experimental } \\
M_{c r c}, \mathrm{kNm}\end{array}$ & $M_{c r, t}, \mathrm{kNm}$ & $\begin{array}{c}\text { Difference } \\
\text { between } M_{c r c} \\
\text { and } M_{c r c, t}, \%\end{array}$ \\
\hline SA6-1 & 3,2 & 2,590 & 23,6 \\
\hline SA6-2 & 3,3 & 3,055 & 8,0 \\
\hline SB6-1 & 2,5 & 2,478 & 0,9 \\
\hline SB6-2 & 3 & 3,091 & 3,0 \\
\hline SC6-1 & 3 & 2,624 & 14,3 \\
\hline SC6-2 & 3 & 3,174 & 5,8 \\
\hline SD6-1 & 3,2 & 2,614 & 22,4 \\
\hline SD6-2 & 3,2 & 3,176 & 0,8 \\
\hline
\end{tabular}


Table 7. Comparison of experimental and calculated cracking moments [21-23]

\begin{tabular}{c|c|c|c}
\hline Beam & $\begin{array}{c}\text { Experimental } \\
M_{c r c}, \mathrm{kNm}\end{array}$ & $M_{c r c, t}, \mathrm{kNm}$ & $\begin{array}{c}\text { Difference } \\
\text { between } M_{c r c} \\
\text { and } M_{c r c, t}, \%\end{array}$ \\
\hline B1 & 17,4 & 14,1 & 23,4 \\
\hline B2 & 16,5 & 12,9 & 27,9 \\
\hline CB1 & 12,3 & 10,5 & 17,1 \\
\hline CB2 & 11,3 & 9,2 & 22,8 \\
\hline CB3 & 12,3 & 10,1 & 21,8 \\
\hline NB1 & 11,4 & 9,2 & 23,9 \\
\hline NB2 & 12,1 & 10,1 & 19,8 \\
\hline 1O & 7,7 & 6,2 & 24,2 \\
\hline 20 & 9,3 & 7,6 & 22,4 \\
\hline
\end{tabular}

Table 8. The calculated and the experimental strengths

\begin{tabular}{c|c|c|c}
\hline Beam & $\begin{array}{c}\text { Experimental } \\
M_{R}, \mathrm{kNm}\end{array}$ & $M_{R, t}, \mathrm{kNm}$ & $\begin{array}{c}\text { Difference } \\
\text { between } M_{R} \\
\text { and } M_{R, t}, \%\end{array}$ \\
\hline SA6-1 & 15,5 & 14,6 & 6,2 \\
\hline SA6-2 & 18 & 15 & 20,0 \\
\hline SB6-1 & 8,8 & 8,1 & 8,6 \\
\hline SB6-2 & 9,6 & 8,5 & 12,9 \\
\hline SC6-1 & 10,4 & 9,7 & 7,2 \\
\hline SC6-2 & 12 & 10 & 20,0 \\
\hline SD6-1 & 11,7 & 10,6 & 10,4 \\
\hline SD6-2 & 14 & 10,9 & 28,4 \\
\hline
\end{tabular}

Table 9. The calculated and the experimental strengths [24-29]

\begin{tabular}{c|c|c|c}
\hline Beam & $\begin{array}{c}\text { Experimental } \\
M_{R}, \mathrm{kNm}\end{array}$ & $M_{R, t}, \mathrm{kNm}$ & $\begin{array}{c}\text { Difference } \\
\text { between } M_{R} \\
\text { and } M_{R, t}, \%\end{array}$ \\
\hline B12u.3 & 42,4 & 43,1 & 1,8 \\
\hline A0 & 20,2 & 16,7 & 21,0 \\
\hline B0 & 21,6 & 25,5 & 17,9 \\
\hline 2C & 15,9 & 14,3 & 11,5 \\
\hline B2 & 18,0 & 16,7 & 7,8 \\
\hline B3 & 21,5 & 20,5 & 5,1 \\
\hline B4 & 20,5 & 23,8 & 16,2 \\
\hline A3 & 19,4 & 14,1 & 37,2 \\
\hline A4 & 18,9 & 14,1 & 33,6 \\
\hline A5 & 21,9 & 19,2 & 14,1 \\
\hline A6 & 21,5 & 19,2 & 12,0 \\
\hline B3 & 131,8 & 126,3 & 4,3 \\
\hline B4 & 130,2 & 126,3 & 3,0 \\
\hline B5 & 147,4 & 168,8 & 14,5 \\
\hline B6 & 142,2 & 168,8 & 18,7 \\
\hline 4 & 6,8 & 6,8 & 0,3 \\
\hline 5 & 7,0 & 6,8 & 2,7 \\
\hline 6 & 6,4 & 8,7 & 35,8 \\
\hline
\end{tabular}

\section{Conclusions}

The use of external carbon fibre in strengthening reinforced concrete structures has significant influence on the cracking moment and the strength. The cracking moment in reinforced concrete beams with external reinfor- cement increases by $56-106 \%$, the strength by $42-$ $190 \%$.

Different methods of anchoring carbon fibre do not have significant influence on the cracking moment of strengthened beams. However, the location of cracks and the manner of their development differ if external reinforcement anchoring methods are used. Anchorage of external reinforcement decreases the influence of displacement of carbon fibre in respect to concrete. The strength of strengthened beams where external reinforcement is anchored is higher by $82 \%$ than of the beams where carbon fibre is not anchored with additional anchors.

By applying theoretical design methods, it is possible to make a rather precise estimation of the cracking moment and strength. The calculated and experimental cracking moments differ by $0,8-27,9 \%$ and the difference of strength results is $0,3-37,2 \%$. In estimating the beams strength with external carbon fibre reinforcement, due to displacement of external reinforcement in respect to concrete, it is essential to evaluate the stiffness of the joint between carbon fibre and concrete.

\section{References}

1. AIELlO, M. A.; OMBRES, L. Cracking and deformability analysis of reinforced concrete beams strengthened with externally bonded carbon fiber reinforced polymer sheet. Journal of Materials in Civil Engineering, 2004, 16(5), p. 392-399.

2. YIN, J.; WU, Z. S. Structural performances of short steelfiber reinforced concrete beams with externally bonded FRP sheets. Construction and Building Materials, 2003, 17(6-7), p. 463-470.

3. YANG, Z. J.; CHEN, J. F.; PROVERBS, D. Finite element modelling of concrete cover separation failure in FRP plated RC beams. Construction and Building Materials, 2003, 17(1), p. 3-13.

4. SMITH, S. T.; TENG, J. G. FRP-strengthened RC beams. I: review of debonding strength models. Engineering Structures, 2002, 24(4), p. 385-395.

5. SEBASTIAN, W. M. Significance of midspan debonding failure in frp-plated concrete beams. Journal of Structural Engineering, 2001, 127(7), p. 792-798.

6. TENG, J. G.; SMITH, S. T.; YAO, J.; CHEN, J. F. Intermediate crack-induced debonding in RC beams and slabs. Construction and Building Materials, 2003, 17(6-7), p. $447-462$.

7. KIM, D.; SEBASTIAN, W. M. Parametric study of bond failure in concrete beams externally strengthened with fibre reinforced polymer plates. Magazine of Concrete Research, 2002, 54(1), p. 47-59.

8. BUYUKOZTURK, O.; GUNES, O.; KARACA, E. Progress on understanding debonding problems in reinforced concrete and steel members strengthened using FRP composites. Construction and Building Materials, 2004, 18(1), p. 9-19.

9. PIMANMAS, A.; PORNPONGSAROJ, P. Peeling behaviour of reinforced concrete beams strengthened with CFRP plates under various end restraint conditions. Magazine of Concrete Research, 2004, 56(2), p. 73-81.

10. GAO, B.; LEUNG, C. K. Y.; KIM, J.-K. Failure diagrams of FRP strengthened RC beams. Composite Structures, 2007, 77(4), p. 493-508. 
11. PHAM, H.; AL-MAHAIDI, R. Experimental investigation into flexural retrofitting of reinforced concrete bridge beams using FRP composites. Composites Structures, 2004, 66(1-4), p. 617-625.

12. BENCARDINO, F.; COLOTTI, V.; SPADEA, G.; SWAMY, R. N. Shear behavior of reinforced concrete beams strengthened in flexure with bonded carbon fibre reinforced polymers laminates. Canadian Journal of Civil Engineering, 2005, 32(5), p. 812-824.

13. GARDEN, H. N.; HOLLAWAY, L. C. An experimental study of the failure modes of reinforced concrete beams strengthened with prestressed carbon composite plates. Composites Part B: Engineering, 1998, 29(4), p. 411424.

14. RAMANA, V. P. V. Behavior of CFRPC strengthened reinforced concrete beams with varying degrees of strengthening. Composites Part B: Engineering, 2000, 31(6-7), p. 461-470.

15. LI, L. J.; GUO, Y. C.; LIU, F.; BUNGEY, J. H. An experimental and numerical study of the effect of thickness and length of CFRP on performance of repaired reinforced concrete beams. Construction and Building Materials, 2006, 20(10), p. 901-909.

16. MOTAK, J.; MACHACEK, J. Experimental behaviour of composite girders with steel undulating web and thinwalled shear connectors hilti stripcon. Journal of Civil Engineering and Management, 2004, 10(1), p. 45-49.

17. BULAVS, F.; RADINSH, I.; TIRANS, N. Improvement of capacity in bending by the use of frp layers on rc beams. Journal of Civil Engineering and Management, 2005, 11(3), p. 169-174.

18. VALIVONIS, J. Deflection of flexural reinforced concrete structures with external non-metallic reinforcement (experimental and theoretical investigation). Journal of Civil Engineering and Management, 2002, 8(3), p. 164168.

19. VALIVONIS, J.; KUDZYS, A.; JURKŠA, A. The resistance of reinforced concrete beams with asbestos cement sheets in the tension zone. Reinforced Concrete Structures
(Gelžbetoninès konstrukcijos), 1987, 15, p. 24-36 (in Lithuanian).

20. RZHANITSYN, A. R. Built-up bars and plates. Moscow: Stroiizdat, 1986. 316 p. (in Russian).

21. ROSS, C. A.; JEROME, D. M.; TEDESCO, J. W. and HUGHES, M. L. Strengthening of reinforced concrete beams with externally bonded composite laminates. ACI Structural Journal, 1999, 96(23), p. 212-220.

22. RITCHIE, P. A. External reinforcement of concrete beams using fiber-reinforced plastics. $\mathrm{PhD}$ thesis, Lehigh University, Pennsylvania, USA, 1990.

23. GAO, B.; KIM, J. K.; LEUNG, C. K. Y. Strengthening efficiency of taper ended FRP strips bonded to RC beams. Composite Science and Technology, 2006, 66(13), p. 2257-2264.

24. GARDEN, H. N.; QUANTRILL, R. J.; HOLLAWAY, L. C.; THORNE, A. M.; PARKE, G. A. R. An experimental study of the anchorage length of carbon fibre composite plates. Construction and Building Materials, 1998, 12(1), p. 203-219.

25. GAO, B.; KIM, J. K.; LEUNG C. K. Y. Experimental study on RC beams with FRP strips bonded with rubber modified resins. Composite Science and Technology, 2004, 64(16), p. 2557-2564.

26. XIONG, G. J.; JIANG, X.; LIU, J. W.; CHEN, L. A way for preventing tension delamination of concrete cover in midspan of FRP strengthened beams. Construction and Building Materials, 2007, 21(2), p. 402-408.

27. MAALEJ, M.; BIAN, Y. Interfacial shear stress concentration in FRP strengthened beams. Composite Structures, 2001, 54(4), p. 417-426.

28. MAALEJ, M.; LEONG, K. S. Effect of beam size and FRP thickness on interfacial shear stress concentration and failure mode of FRP-strengthened beams. Composite Science and Technology, 2005, 65, p. 1148-1158.

29. TRIANTAFILlOU, T. C.; PLEVRIS, N. Strengthening of rc beams with epoxy bonded fibre composite materials. Materials and Structures, 1992, 25(4), p. 201-211.

\section{ANGLIES PLUOŠTU ARMUOTU LENKIAMŲJŲ KONSTRUKCIJỤ PLEIŠĖTUMAS IR STIPRUMAS}

\section{J. Valivonis, T. Skuturna}

S antrauka

Straipsnyje analizuojamas sijų su išorine anglies pluošto armatūra plyšių susidarymo momentas ir stiprumas. Atlikti anglies pluoštu sustiprintų sijų eksperimentiniai tyrimai. Trys skirtingi išorinès armatūros inkaravimo būdai buvo pritaikyti sijoms stiprinti. Nustatyta inkaravimo įtaka plyšių susidarymo momentui ir stiprumui. Pateikti skaičiavimo metodai plyšiu susidarymo momentui ir stiprumui nustatyti. Plyšių susidarymo momento skaičiavimo metodika pagrisstos kreivalinijinės tempiamojo ir gniuždomojo betono itempių diagramos, o konstrukcijų stiprumo skaičiavimu ịvertintas anglies pluošto ir betono kontakto standumas. Pateikti skaičiavimo rezultatai. Atlikta eksperimentinių ir teorinių rezultatų palyginimo analizè.

Reikšminiai žodžiai: išorinė anglies pluošto armatūra, stiprinimas, plyšių susidarymo momentas, stiprumas.

Juozas VALIVONIS. Doctor, Associate Professor at the Dept of Reinforced Concrete and Masonry Structures, Vilnius Gediminas Technical University (VGTU), Sauletekio al. 11, LT-10223, Vilnius, Lithuania. E-mail: gelz@ st.vgtu.lt Author of over 55 publications. Research interests: theory of reinforced concrete behaviour, composite structures, reinforced concrete bridges.

Tomas SKUTURNA. PhD student at the Dept of Reinforced Concrete and Masonry Structures, Vilnius Gediminas Technical University (VGTU), Saulètekio al. 11, LT-10223, Vilnius, Lithuania. E-mail: tomas.skuturna@st.vgtu.lt Research interests: composite structures, strengthening the reinforced concrete structures. 